\title{
Is Financial Performance Reflected in Stock Prices?
}

\author{
Zarah Puspitaningtyas \\ Department of Business Administration \\ University of Jember \\ Jember, Indonesia \\ zarah@unej.ac.id
}

\begin{abstract}
Investors need relevant information for making investment decisions in the stock market. Therefore, we need an approach to analyze stock prices, one of which is the fundamental approach. Fundamental approach basing its analysis on the assumption that stock prices reflect the fundamental performance of a company. Is the financial performance reflected in stock prices? The purpose of this study was to determine the effect of the financial performance of the stock price. Financial performance is measured using the variables of liquidity, profitability, growth, and market valuation. The population of this study is a non-banking company registered in the Indonesia Stock Exchange and incorporated in LQ45 Index in the period 20112016. Sampling was done by using the purposive technique. Furthermore, the data were analyzed using multiple linear regression methods. At the 0.05 level of significance, the results showed that only market valuation variables that significantly influence stock prices. Meanwhile, the variable liquidity, profitability, and growth have no effect on stock prices. These results indicate that the share price reflects the market valuation of the company's shares.
\end{abstract}

Keywords: financial performance; stock prices; investment decision

\section{Introduction}

Investment is an activity of allocating funds to an asset over a certain period in the hope of obtaining a future rate of return. Rational investors always consider accounting information in the investment decision-making process. In general, accounting information is presented in the company's financial statements and reflects the company's performance over a period. For investors, information about the company's financial performance is useful in making investment decisions. Decision-making is a process of selecting the best alternative from the various alternatives available under the influence of complex situations. Investor behavior in investment decision-making process will be greatly influenced by various information received, also knowledge and ability of investor in investment analysis (Puspitaningtyas, 2012a; 2012b; 2013; 2015; 2017; Puspitaningtyas \& Kurniawan, 2012).

The stock is one type of securities traded in the capital market. Investing in stocks is one type of investment that offers a high rate of return, although it also contains a high level of risk because it has a high degree of uncertainty. Investment theory states that there is a positive and linear relationship between return and investment risk. Therefore, a high rate of return reflects the high level of risk that 
investors will incur on their investment. There are two types of returns in stock investments, namely dividends and capital gains. Dividends are the share of profits distributed to investors based on the proportion of share ownership. Meanwhile, capital gains represent returns obtained from the difference between the purchase price and the selling price of the shares (Bodie et al., 2009; Scott, 2009; Tandelilin, 2010; Puspitaningtyas, 2012a; 2012b; 2015; 2017; Puspitaningtyas \& Kurniawan, 2012; Mustofia et al., 2014).

A high degree of uncertainty in stock investments, encouraging investors to behave rationally in their investment decisions. The investment decision is to buy, sell, or retain ownership of its shares. The rational behavior in question is not being speculative, but investors will consider or analyze relevant information as the basis for their investment decisions. The ability to analyze is influenced by the level of knowledge and investment experience of investors. Therefore, in an effort to minimize the risk level, investors should conduct stock valuations. Stock valuation can be done with two approaches, namely technical analysis, and fundamental analysis. Technical analysis is based on past stock price movements as an effort to predict future stock prices (the tendency for short-term goals), whereas fundamental analysis is based on the company's financial performance information as an effort to assess stocks and predict the direction of stock price movements (tendency for longterm goals) (Halim, 2005; Scott, 2009; Brigham \& Houston, 2009; Puspitaningtyas, 2007; 2013; 2015; 2017).

The stock market price is the stock price determined by the interaction of market participants on the demand and supply of a share. The price reflects the stock price that occurs in the stock market at a given moment. Stock prices should reflect a company's financial performance. When a company's financial performance increases, the market will appreciate with rising stock prices, and vice versa. In other words, the company's financial performance should be reflected in the stock price. If the financial performance increases, then the tendency of shares of the company will be favored by investors, thus encouraging the increase in stock prices (Husnan, 2005; Elliott \& Schaub, 2006; Ragab \& Omran, 2006; Brealey et al., 2007; Hartono, 2009; Tandelilin, 2010; Zingales, 2010; Aono \& Iwaisako, 2011; Anderson et al., 2012; Sandy \& Asyik, 2013; Amanah et al., 2014; Talamati \& Pangemanan, 2015; Sun et al., 2016). It shows that there is a positive relationship between financial performance and stock price. The higher the financial performance the higher the stock price, and vice versa.

Although theoretically, the company's financial performance has an effect on stock prices, empirically some previous studies have inconsistent results. It became an interest to conduct further study. The purpose of this study is to determine the effect of financial performance on stock prices company. Financial performance is analyzed based on the firm's fundamental information measured using liquidity variables (using current ratio indicators), profitability (using return on equity indicators), growth (using growth indicators), and market valuation (using earning per share indicators). The study population is a non-banking company listed on the Indonesia Stock Exchange and incorporated in the LQ45 Index in the period 20112016. Sampling is done by purposive technique. Furthermore, the data were analyzed by using multiple linear regression methods and the decision was taken based on the 0.05 level of significance. 


\section{Literature Review}

\section{Financial Performance and the Movement of Stock Price}

Some financial literature states that stock prices should reflect a company's financial performance. The higher the stock price reflects the company's financial performance is also higher. In other words, the higher the financial performance of a company, the higher the stock price level in the stock market (Elliott \& Schaub, 2006; Ragab \& Omran, 2006; Brealey et al., 2007; Jacob \& Harahap, 2007; Hartono, 2009; Tandelilin, 2010; Talamati \& Pangemanan, 2015).

Assessment of financial performance can be done using fundamental analysis, namely through the measurement of financial ratios as an indicator. Investors can use fundamental analysis to predict the movement of stock prices. Fundamental analysis can describe the company's condition and future prospects. Financial ratio measurement is an instrument of company performance analysis that shows changes in financial position in a certain period and describes the trend of change. There are several financial ratios as a tool for assessing financial performance, including liquidity, leverage, activity, profitability, growth, and valuation (Fahmi, 2012; Puspitaningtyas, 2012a; 2015; 2017).

Theoretically mentioned that the company's financial performance is reflected in the stock price. If the financial performance indicates a good prospect, then the stock will be favored by investors, so that will encourage the increase in stock prices. It shows that there is a positive relationship between financial performance and stock price. A good financial performance will be appreciated by the market in the form of rising stock prices. Conversely, poor financial performance will be followed by a decline in stock prices. Husnan (2005) and Puspitaningtyas (2015) argues that the value of stock reflects the value of the company. Therefore, the management of the company will seek to improve its financial performance to encourage the increase in stock prices.

This study explains the relationship between financial performance and stock price movements based on agency theory and signaling theory. The agency theory states that the investor (as principal) requires the management of the company (as agent) to make efforts in order to improve the company's financial performance which can be presented in the financial ratios. When an increase in financial performance is achieved, then the market will appreciate in the form of an increase in stock prices following an increase in market demand by the market. Agency theory explains that corporate management as a party contracted by shareholders must work in the interests of shareholders. Company management is given the authority to make the best policy (decision) for the improvement of shareholder's welfare. Therefore, the company's management must take account of the management of the company presented in the company's financial statements periodically (Scott, 2009).

The information presented in the company's financial report becomes a signal for investors in making investment decisions. Relevant and reliable information is needed for investors as an analytical tool in making investment decisions. When the published information contains a positive value (good news), then the trend of the market will react positively. Based on signaling theory, the motivation of company management to present financial information is to give a signal of prosperity for shareholders, both in the form of dividend growth and increase in stock price. The underlying concept is that the value of a company's stock is influenced by the financial performance of the company. However, information is individual, meaning that individuals may respond differently to the same source of information (Hartono, 
2009; Scott, 2009; Vice \& Lauw, 2011; Puspitaningtyas, 2012b; 2015; 2017; Eliza, 2013).

The financial performance assessment in this study was conducted using four variables, namely: 1) liquidity, measured using current ratio indicator; 2) profitability, measured using the return on equity indicator; 3) growth, measured using sales growth indicators; and 4) market valuation, measured using the earning per share indicator. Figure 1 presents the conceptual framework of this study. Next, we will describe the relationships among variables analyzed in this study.

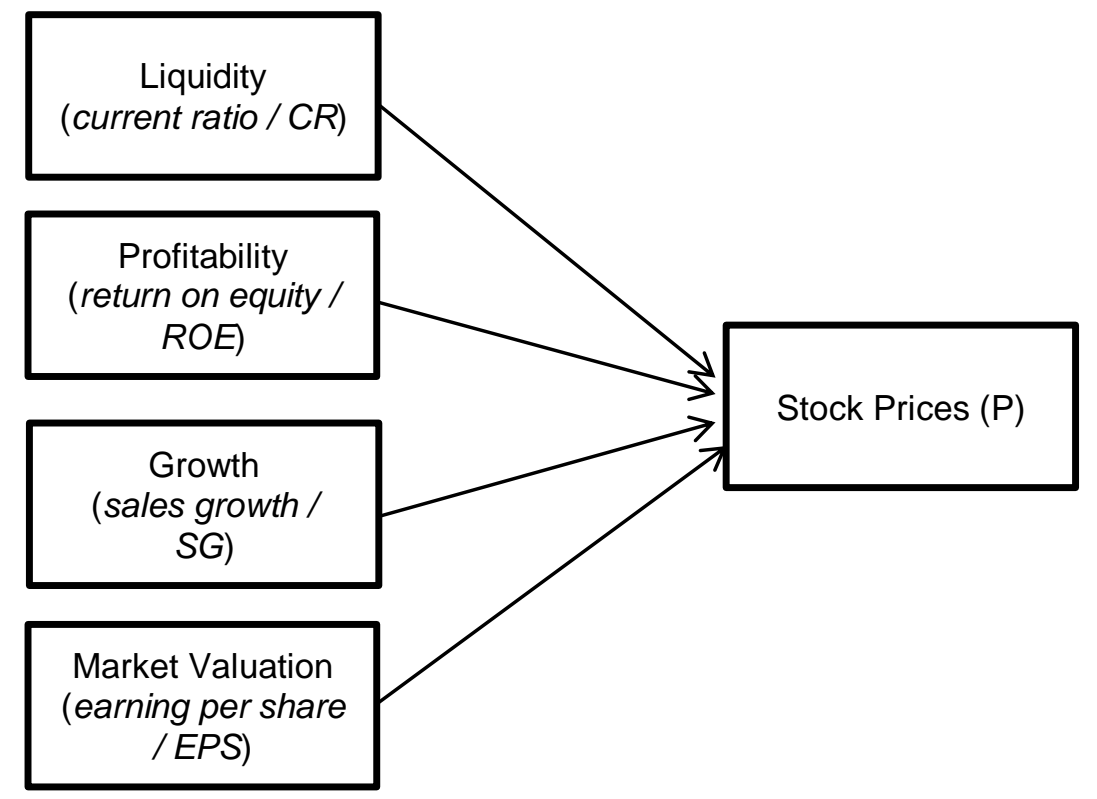

Figure 1. Conceptual Framework

\section{Liquidity and Stock Prices}

Liquidity indicates a company's ability to pay short-term financial liabilities when it matures with all available current assets. A high level of liquidity reflects the company's financial condition in good condition. If the level of liquidity is low, it will create an illiquid financial condition. However, too high levels of liquidity can also have a material adverse effect on the company's financial condition, because it reflects the availability of overly high current assets or indicates a lot of idle funds (Syamsuddin, 2007; Panwala, 2009; Harahap, 2010; Puspitaningtyas, 2010; 2011; 2012a; 2015; 2017; Puspitaningtyas \& Kurniawan, 2012; Niresh, 2012; Eliza, 2013; Rajdev, 2013; Putra et al., 2014; Ismail, 2016).

This study measures liquidity by using the current ratio indicator. The current ratio is the ratio of current assets and current liabilities in a period. This measurement shows the company's ability to pay current liabilities with current assets available. The higher the current ratio means the better the company's ability to pay off its short-term liabilities. This condition reflects that the company is not in a liquidity problem. The higher the current ratio of a company means the less risk of a company's failure to meet its short-term liabilities. Therefore, information about a good current ratio will be appreciated by the market in the form of rising stock prices following the increase in the company's stock demand.

This study predicts that there is a positive relationship between liquidity (using current ratio indicators) and stock prices. This prediction refers to the result of a study by Wicaksono (2013), Amanah et al. (2014), and Surya (2016) which proves 
that liquidity (using current ratio indicator) has an effect on stock price. Meanwhile, the results of a study by Meythi et al. (2011) proves that liquidity (using current ratio indicator) has no effect on stock price. Current ratio $\left(C R_{t}\right)$ is measured using the formula: Current Assets $\left(C A_{t}\right)$ / Current Liabilities $\left(C L_{t}\right)$.

$\mathrm{H}_{1}$ : liquidity affects stock prices

\section{Profitability and Stock Prices}

Profitability demonstrates a company's ability to profit from the amount of funds invested in overall assets (Syamsuddin, 2007; Panwala, 2009; Puspitaningtyas, 2010; 2011; 2012a; 2015; 2017; Puspitaningtyas \& Kurniawan, 2012; Niresh, 2012; Asmawati \& Amanah, 2013; Rajdev, 2013; Mustofia et al., 2014; Ismail, 2016; Jami \& Bahar, 2016; Ulfa et al., 2016). This study measures profitability using return on equity indicators. Return on equity is the ratio of earning after taxes and total equity in a period. This measurement demonstrates a company's ability to manage its own resources to earn a return on equity. Return on equity is a measurement of the available income for shareholders of the funds they invest in the company (Syamsuddin, 2007; Fahmi, 2012; Ariyanti et al., 2016; Aryani et al., 2016). The higher return on equity reflects the company in a profitable condition. Profitable corporate conditions will drive an increase in stock prices following an increase in market demand for company stocks.

This study predicts that there is a positive relationship between profitability (using return on equity indicators) and stock prices. This prediction refers to the results of studies by Hartono \& Sitohang (2008), Deitiana (2011), Nurfadillah (2011), Hutami (2012), Rahmandia (2013), and Kussuma et al. (2016) which proves that profitability (using indicators of return on equity) affect stock prices. Meanwhile, the results of studies by Budiman (2007), Amanah et al. (2014), Ariyanti et al. (2016), and Surya (2016) proves that profitability (using the return on equity indicator) does not affect the stock price. Return on equity $\left(R O E_{t}\right)$ is measured using the formula: earning after taxes $\left(E A T_{t}\right) /$ total equity $\left(T E_{t}\right)$.

$\mathrm{H}_{2}$ : profitability affects stock prices

\section{Growth and Stock Prices}

The growth variable reflects the company's ability to maintain its economic position in industrial economic growth. The high growth rate reflects the company having the opportunity to earn excess earnings (Puspitaningtyas, 2010; 2011; 2015; Sitanggang, 2012). This study measures growth variables using sales growth indicators. Sales growth is defined as a change of sales in a period. High sales growth and accompanied by cost efficiency will encourage the achievement of increased profit. In addition, high sales growth also reflects the company's ability to meet its financial obligations if the company finances its asset expenditures with debt (Kesuma, 2009). Sales growth reflects the success of the company, this condition will encourage the increase in stock prices following the increase in market demand for the company's shares.

This study predicts that there is a positive relationship between growth (using growth indicators) and stock prices. This prediction does not refer to the results of studies by Deitiana (2011), Rahmandia (2012), Mahapsari \& Taman (2013), Bailia et al. (2016), and Surya (2016) which proves that sales growth does not affect the stock price. Sales growth $\left(S G_{t}\right)$ is calculated by using the formula: total sales $t\left(T S_{t}\right) /$ total salest-1 $\left(T S_{t-1}\right)$.

$H_{3}$ : growth affects stock prices 


\section{Market Valuation and Stock Prices}

The stock valuation or market valuation variable is an indicator of the investor's interest in buying a company's stock. In other words, this variable reflects the market valuation (investor) of the firm's value. The higher level of market valuation then the company is considered to have a good performance (Puspitaningtyas, 2015).

This study measures the market valuation using the earning per share indicator. Some financial literature states that earnings per share are included in profitability indicator, but some mention that earnings per share included an indicator of market valuation. This study uses earnings per share as an indicator of market valuation. Earning per share is the net profit available to be distributed to shareholders divided by the number of shares of the company in a period. Earning per share is the most important component of fundamental analysis that investors use to make investment decisions. Investors are very interested in earnings per share because they represent the amount of rupiah earned for each common share. Therefore, earnings per share are one indicator of corporate success (Tandelilin, 2010; Puspitaningtyas, 2015).

The higher level of earnings per share indicates the greater ability of a company to generate a net profit proportion on each share. It reflects that the company has achieved success in its business activities and succeeded in the welfare of its shareholders (Brigham \& Houston, 2009; Fahmi, 2012). Therefore, high earning per share will push the stock price up.

This study predicts that there is a positive relationship between market valuation (using earning per share) and stock prices. This prediction supports the results of studies by Budiman (2007), Pasaribu (2008), Priantinah \& Kusuma (2012), Ariyanti et al. (2016), and Aryani et al. (2016) which proves that market valuation (using earning per share indicator) influences stock prices. Meanwhile, the results of a study by Zen (2009), Meythi et al. (2011), and Kussuma et al. (2016) proves that market valuation (by using earnings per share) does not affect the stock price. Earning per share $\left(E P S_{t}\right)$ is calculated using the formula: earnings after taxes $\left(E A T_{t}\right)$ / number of shares $\left(N S_{t}\right)$.

$\mathrm{H}_{4}$ : market valuation affects stock prices

\section{Methodology}

The population of this study is a non-banking company listed on the Indonesia Stock Exchange during the period 2011-2016, which amounted to 45 companies. Based on the population, then selected the sample using purposive sampling technique. Sampling criteria are companies that are consecutively incorporated in the LQ45 Index during the study period, ie 2011-2016 (six years). The reason for the use of shares in the LQ45 Index, because these shares are actively traded shares and the company's financial condition is considered good with good growth prospects also in the future. LQ45 shares have a market capitalization value of about $70 \%$ of stocks listed on the Indonesia Stock Exchange so that LQ45 shares are stocks of interest to investors. Based on the sampling criteria is obtained the number of samples of 9 companies. Furthermore, based on pooling data then the data analyzed is a number of 54 observations $(n=54)$. The data used for the analysis is secondary data, the name information presented in the company's financial statements for the period 2011-2016. 
The collected data then tested the classical assumption, namely: normality test, multicollinearity test, heteroscedasticity test, and autocorrelation test. The classical assumption test shows the result that the analyzed data meets the classical assumption, so it is feasible to do multiple linear regression analysis. Furthermore, the data were analyzed using multiple linear regression methods using SPSS software. Before testing the hypothesis is done (ie: t-test), firstly feasibility testing model (ie: coefficient of determination $\left(R^{2}\right)$ and Test $F$ ). The t-test is performed to determine whether the independent variables (ie: liquidity, profitability, growth, and market valuation) affect the dependent variable (ie: stock price). The stock price used in this study is the closing price.

\section{Results and Discussion}

Multiple linear regression analysis was conducted to determine the effect of liquidity, profitability, growth, and market valuation of stock prices. Table 1 presents the results of multiple linear regression analysis.

Table 1. Results of Multiple Linear Regression Analysis

\begin{tabular}{|c|c|c|c|c|c|}
\hline \multicolumn{3}{|l|}{ Multiple R } & 0.451 & & \\
\hline \multicolumn{3}{|l|}{ R Square } & 0.389 & & \\
\hline \multirow{2}{*}{\multicolumn{3}{|c|}{$\begin{array}{l}\text { Adjusted R Square } \\
\text { Standard Error of }\end{array}$}} & 0.370 & & \\
\hline & & & & & \\
\hline \multicolumn{3}{|l|}{ Estimate } & 0.72952 & & \\
\hline \multicolumn{3}{|l|}{ F Value } & 25.923 & & \\
\hline \multicolumn{3}{|l|}{ Sig. $F$} & 0.000 & & \\
\hline \multicolumn{6}{|c|}{ Variable in the equation } \\
\hline Variable & B & Std. Error & Beta & $\mathbf{T}$ & Sig. \\
\hline $\mathrm{Li}$ & -5.307 & 5.050 & -0.066 & -1.059 & 0.302 \\
\hline $\operatorname{Pr}$ & -114.023 & 115.135 & -0.107 & -0.980 & 0.325 \\
\hline $\mathrm{Gr}$ & -23.471 & 38.202 & -0.025 & -0.415 & 0.685 \\
\hline MV & 20.279 & 719 & 0.948 & 15.368 & 0.000 \\
\hline (Constant) & 7971.025 & 2125.910 & & 2.688 & 0.000 \\
\hline
\end{tabular}

Source: results of the analysis

Based on these results seen that the value of determination coefficient $\left(R^{2}\right)$ obtained is small $\left(R^{2}=0.389\right)$. That is, the regression equation model generated shows that the ability of variable liquidity (using current ratio indicator), profitability (using return on equity indicator), growth (using growth indicator), and market valuation (using earning per share indicator) in explaining the variation of stock price variables is limited, ie only by $38.9 \%$. Meanwhile, the remaining $61.1 \%$ is explained by other variables (e) not observed.

The test value $F=25.923$, significant at the 0.05 significance level. That is, all independent variables contained in the regression equation model, ie liquidity (using current ratio indicator), profitability (using return on equity indicators), and market valuation (using earning per share) simultaneously have a significant effect on price variables stock.

At the 0.05 significance level, the results show that only the market valuation (using earning per share indicator) has a significant effect on the stock price ( $\mathrm{H} 4$ is 
received). On the other hand, liquidity (using current ratio indicator), profitability (using return on equity indicator), and growth (using growth indicator) have no effect on stock price $(\mathrm{H} 1, \mathrm{H} 2$, and $\mathrm{H} 3$ are rejected). The results of the analysis can be derived in the equation model as follows: $P=7971.025+20.279$ EPS + e. The equation model shows that market valuation (by using earning per share indicator) has a positive effect on stock price. That is, the results of the analysis of this study prove that the market valuation is reflected in stock prices.

The results of this study indicate that investors in their investment decisions consider the financial performance of achieving the proportion of earnings per share and do not see the financial performance of the achievement of liquidity, profitability, and sales growth. Because only a market assessment that proved to affect the stock price. That, the movement of the company's stock price is influenced by market valuation. Any change in market valuation (in this case the value of earnings per share) will tend to provide a direct movement of stock prices. The financial information available in the Indonesian capital market may not be favorable to investors as a consideration in the investment decision-making process, thus showing the result that liquidity, profitability, and growth, as part of the financial performance assessment, have no effect on stock prices.

Earning per share is a concern for investors because it shows the amount of profit generated from each share owned by shareholders. The greater the value of earning per share, the greater the profit earned by shareholders. As an indicator of market valuation, earnings per share provide information to investors associated with the value of the company, so it can be considered for investors to make investment decisions. When the value of earnings per share is high, then the trend of stock prices will increase following the increase in demand for the company's shares. Therefore, the value of a high earning per share will encourage stocks in demand by the market.

The results of the study prove that liquidity (using current ratio indicator) does not affect the stock price. The argument is that the current ratio as an indicator of liquidity has its limitations because the current ratio is seen as a static measure. That is, the available current assets are deemed not to represent future cash inflows. In addition, investors tend to assume that company management makes use of the current ratio for "window dressing", in which the company's management strives to take certain steps to make the balance sheet look good, resulting in a good liquidity rating. Therefore, investors tend not to use liquidity as a consideration and investment decision-making process. Thus, liquidity is seen not reflected in the stock price (Meythi et al., 2011).

The results of the study also prove that profitability (using the return on equity indicator) and growth (using the sales growth indicator) does not affect the stock price. These results indicate that investors are not considering both variables in their investment decisions. Possible stock prices tend to be formed due to market sentiment, speculation, and influenced by economic issues so that the stock price formed does not reflect the profitability and growth of the company. Alternatively, investors rationally pay attention only to the earnings per share that are expected to be received, compared to the assessment of other financial performance indicators.

As a limitation of this study, the results of multiple linear regression analysis proved that the ability of the variables of financial performance assessment (ie: liquidity, profitability, growth, and market valuation) in explaining variations in stock price variables is limited. This shows that there are still many other variables that affect the stock price of the company. This study considers only four variables of 
financial performance assessment. Subsequent research can consider other variables of financial performance assessment that predicted to affect stock price, for example, activity variable (using indicator: total assets turnover and inventory turnover).

\section{Conclusion}

Based on the analysis result, it can be concluded that at the 0.05 significance level only the market valuation variables (using the earning per share indicator) significantly affect the stock price, meaning that only the market valuation variables are reflected in the stock price. In other words, the results of this study show that stock prices reflect the market valuation of the company's stock. Meanwhile, the liquidity, profitability, and growth variables are assessed to have no direct impact that could affect the stock price of the company's shares, since the three variables of the financial performance indicate no effect on the stock price.

\section{References}

Amanah, R., Atmanto, D., \& Azizah, DF. 2014. Pengaruh rasio Likuiditas dan Rasio Profitabilitas terhadap Harga Saham: Studi pada Perusahaan Indeks LQ45 Periode 2008-2012. Jurnal Administrasi Bisnis, 12(1): 1-10.

Anderson, M., Garling, T., Hedstrom, M., \& Biel, A. 2012. Effect on Stock Investments of Information about Short versus Long Price Series. Review of Behavioral Finance, 4(2): 81-97.

Aono, K., \& Iwaisako, T. 2011. Forecasting Japanese Stock Returns with Financial Ratios and Other Variables. Asia-Pacific Finan Markets, 18: 373-384.

Ariyanti, S., Topowijono, \& Sulasmiyati, S. 2016. Pengaruh Profitabilitas dan Leverage terhadap Harga Saham: Studi pada Perusahaan Konstruksi dan Bangunan yang Terdaftar di Bursa Efek Indonesia Periode 2011-2014. Jurnal Administrasi Bisnis, 35(2): 181-188.

Aryani, YA, Zulkifli, \& Alfian, M. 2016. Pengaruh Rasio Profitabilitas terhadap Harga Saham pada Perusahaan Industri Logam dan Sejenisnya yang Terdaftar di Bursa Efek Indonesia. Jurnal Akuntansi Politeknik Sekayu, 4(1): 23-31.

Asmawati, \& Amanah, L. 2013. Pengaruh Struktur Kepemilikan, Keputusan Keuangan terhadap Nilaia Perusahaan: Profitabilitas sebagai Variabel Moderating. Jurnal IImu \& Riset Akuntansi, 2(4): 1-18.

Bailia, FFW., Tommy, P., \& Baramulli, DN. 2016. Pengaruh Pertumbuhan Penjualan, Dividend Payout Ratio dan Debt to Equity terhadap Harga Saham pada Perusahaan Property di Bursa Efek Indonesia. Jurnal Berkala IImiah Efisiensi, 16(3): 270-278.

Bodie, Z., Kane, A., \& Marcus, AJ. 2009. Investment. $8^{\text {th }}$ edition. McGraw-Hill Companies, Inc.

Brealey, RA, Myers, SC, \& Marcus, AJ. 2007. Dasar-Dasar Manajemen Keuangan Perusahaan. (Terjemahan Bob sabran, 2008, edisi 5). Jakarta: Erlangga.

Brigham, EF., \& Houston, JF. 2009. Fundamentals of Financial management. United States of America: Harcourt College.

Budiman, ISK. 2007. Analisis Hubungan Profitabilitas dengan Harga Saham Sektor Usaha Makanan dan Minuman di Bursa Efek Jakarta. Journal The Winners, 8(1): 1-23. 
Deitiana, T. 2011. Pengaruh Rasio Keuangan, Pertumbuhan Penjualan dan Dividen terhadap Harga Saham. Jurnal Bisnis dan Akuntansi, 13(1): 57-66.

Eliza. 2013. Hubungan Nilai Intrinsik Suatu Saham Terhadap Harga Pasar Saham Tersebut. Jurnal Ekonomi, 4(1): 29-37.

Elliott, RS., \& Schaub, M. 2006. On the New York Stock Exchange: A Look at Investment Opportunities. International Business \& Economics Research Journal, 5(3): 7-14.

Fahmi, I. 2012. Analisis Laporan Keuangan. Bandung: Alfabeta.

Halim, A. 2005. Analisis Investasi. Edisi 2. Jakarta: salemba Empat.

Harahap, SS. 2010. Analisis Kritis atas Laporan Keuangan. Jakarta: Rajawali Pers.

Hartono, J. 2009. Teori Portofolio dan Analisis Investasi. Yogyakarta: BPFE.

Hartono, \& Sitohang, RP. 2008. Analisis Hubungan Profitabilitas dengan Pergerakan Harga Saham pada Sektor Usaha Perbankan di Bursa Efek Indonesia. Journal of Applied Finance and Accounting, 2(2): 51-66.

Husnan, S. 2005. Dasar-Dasar Teori Portofolio dan Analisis Sekuritas. Edisi Keempat. Yogyakarta: Sekolah Tinggi IImu Manajemen YKPN.

Hutami, RP. 2012. Pengaruh Dividend Per Share, Return on Equity, dan Net Profit Margin terhadap Harga SahamPerusahaan Industri Manufaktur yang tercatat di Bursa Efek Indonesia periode 2006-2010. Jurnal Nominal, 1(1): 104-123.

Ismail, R. 2016. Impact on Liquidity Management on Profitability of Pakistani Firms: A Case of KSE-100 Index. International Journal of Innovation and Applied Studies, 14(2): 304-314.

Jacob, RH., \& Harahap, SS. 2007. Hubungan antara Indikator Mikro dan Makro terhadap Nilai Buku dan Harga Pasar Saham Perusahaan. Media Riset Akuntansi, Auditing dan Informasi, 7(2): 217-261.

Jami, M. and Bahar, M.N. 2016. Analysis of Profitability Ratios to Evaluation of Performance of Indian Automobile Industry. Journal of Current Research in Science, 747-755.

Kesuma, A. 2009. Analisis Faktor yang Mempengaruhi Struktur Modal serta Pengaruhnya terhadap Harga Saham Perusahaan Real Estate yang Go Public di BEl. Jurnal Manajemen \& Kewirausahaan, 2(1): 38-45.

Kussuma, P., Surachim, A., \& Tanuatmodjo, H. 2016. Dampak Tingkat Profitabilitasdan Nilai Pasar pada Pergerakan Harga Saham PT. Prasidha Aneka Niaka, Tbk. Journal of Business Management Education, 1(2): 97-103.

Mahapsari, NR., \& Taman A. 2013. Pengaruh Profitabilitas, Struktur aktiva, dan Pertumbuhan Penjualan terhadap Harga Saham dengan Struktur Modal sebagai Variabel Intervening pada Perusahaan Manufaktur di Bursa Efek Indonesia. Jurnal Nominal, 2(1): 137-158.

Meythi, En, TK., \& Rusli, L. 2011. Pengaruh Likuiditas dan Profitabilitas terhadap Harga Saham Perusahaan Manufaktur yang Terdaftar di Bursa Efek Indonesia. Jurnal Bisnis Manajemen dan Ekonomi, 10(2): 2671-2684.

Mustofia, M., Puspitaningtyas, Z., \& Sisbintari, I. 2014. Pengaruh Profitabilitas dan Investment Opportunity Set terhadap Kebijakan Dividen. Jurnal Akuntansi Aktual, 2(4): 219-228.

Niresh, J. A. 2012. Trade-off Between Liquidity \& Profitability: A Study Of Selected Manufacturing Firms in Sri Lanka. Researchers World, 3(4): 34-40.

Nurfadillah, M. 2011. Analisis Pengaruh Earning Per Share, Debt to Equity Ratio dan Return on Equity terhdapa Harga Saham PT. Unilever Indonesia, Tbk. Jurnal Manajemen dan Akuntansi, 12(1): 45-50. 
Panwala, M. 2009. The dimension of Liquidity Management - a Case Study of the Surat Textile's Traders Co-Operative Bank LTD, Surat. National Journal of System and Information Technology, 2(1): 117-126.

Pasaribu, RBF., 2008. Pengaruh Variabel Fundamental terhadap harga saham Perusahaan Go Public di Bursa efek indonesia (BEI) Periode 2003-2006. Jurnal ekonomi \& Bisnis, 2(2): 101-113.

Priantinah, D., \& Kusuma, PA. 2012. Pengaruh Return on Investment (ROI), Eraning Per Share (EPS), dan Dividend Per Share (DPS) terhadap Harga Saham Perusahaan Pertambangan yang terdaftar di Bursa Efek Indonesia (BEI) Periode 2008-2009. Jurnal Nominal, 1(1): 50-64.

Puspitaningtyas, Z. 2007. Pemanfaatan Informasi Akuntansi Bagi Investor dalam Proses Pengambilan Keputusan Investasi. Jurnal NEO-BIS: Jurnal Neraca, Ekonomi dan Bisnis, 1(2): 121-129.

. 2010. Manfaat Informasi Akuntansi untuk Memprediksi Risiko Investasi saham Berdasarkan Pendekatan Decision Usefulness. Jurnal Akuntansi Multiparadigma, 1(3): 467-488.

2011. Pembentukan Model Prediksi Risiko Investasi Saham Berdasarkan Pendekatan Decision Usefullness Approach of Accounting Information. Prosiding Seminar Nasional dan Call for Paper 2011: Kajian Penelitian Aktual Guna Pengembangan Teori Baru Bidang Ekonomi dan Bisnis, 43-58.

2012a. Pengaruh Rasio Likuiditas dan Financial Leverage terhadap Dividend Yield. Jurnal Ekonomi \& Bisnis, 6(1): 41-46. 2012b. Relevansi Nilaia Informasi Akuntansi dan Manfaatnya Bagi Investor. Ekuitas: Jurnal Ekonomi dan Keuangan, 16(2): 164-183. . 2013. Perilaku Investor dalam Pengambilan Keputusan Investasi di Pasar Modal. Prosiding Forum Manajemen Indonesia ke 5, Pontianak. 2015. Prediksi Risiko Investasi Saham: Decision Usefulness Approach. Yogyakarta: Griya Pandiva.

. 2017. Estimating Systematic Risk for the Best Investment Decision on Manufacturing Company in Indonesia. Investment Management \& Financial Innovation, 14(1): 46-54.

Puspitaningtyas, Z., \& Kurniawan, A. 2012. Prediksi Tingkat Pengembalian Investasi Berupa Dividend Yield Berdasarkan Analisis Financial Ratio. Majalah EKONOMI: Telaah, Manajemen, Akuntansi dan Bisnis, 16(1):89-98.

Putra, A. P., Lahinch, L., \& Bambang, R. 2014. Financial Performance Analysis Before and After Global Crisis (Case Study in Indonesian Oil and Gas Sector for the Period of 2016-2011). Review of Integrative Business and Economics Research, 3(1): 42-51.

Ragab, AA., \& Omran, MM. 2006. Accounting Information, Value Relevance, and Investors; Behavior in the Egyptian Equity Market. Review of Accounting and Finance, 5(3): 279-297.

Radjev, A. 2013. Working Capital Management of Makson Healthcare PVT LTD: a Trade-off Between Liquidity and Profitability, an Empirical Study. International Refereed Research Journal, 4(3): 87-94.

Rahmandia, F. 2013. Faktor-Faktor yang Mempengaruhi Harga Saham Perusahaan di Sektor Industri Barang Konsumsi yang Terdaftar di BEI Periode 2007-2011. Jurnal IImiah Universitas Surabaya, 2(1). 
Sandy, A. \& Asyik, NF. 2013. Pengaruh Profitabilitas dan Likuiditas terhadap Kebijakan Dividen Kas pada Perusahaan Otomotif. Jurnal IImu dan Riset Akuntansi, 1(1): 59-76.

Scott, WR. 2009. Financial Accounting Theory. Fourth Edition. Toronto, Ontario: Pearson Education Canada, Inc.

Sitanggang, JP. 2012. Manajemen Keuangan Perusahaan. Jakarta: Mitra Wacana Media.

Sun, XQ., Shen, HW, Cheng, XQ, \& Zhang, Y. 2016. Market Confidence Predicts Stock Price: Beyond Supply and Demand. PloS ONE, 11(7): 1-10.

Surya, YYA. 2016. Analisis Pengaruh Rasio Keuangan, Pertumbuhan Penjualan dan Dividen terhadap Perubahan Harga Saham Perusahaan Consumer Goods: Studi Empiris pada Perusahaan Layanan Telekomunikasi di Bursa Efek Indonesia Tahun 2011-2015. Jurnal Kajian Bisnis, 24(2): 181-195.

Syamsuddin, L. 2007. Manajemen Keuangan Perusahaan: Konsep Aplikasi dalam Perencanaan, Pengawasan, dan Pengambilan Keputusan. Jakarta: Rajawali Pers.

Talamati, M., \& Pangemanan, S. 2015. The Effect of Earnings Per Share (EPS) \& Return on Equity (ROE) on Stock Price of Banking Company Listed in Indonesia Stock Exchange (IDX) 2010-2014. Jurnal EMBA, 3(2): 1086-1094.

Tandelilin, E. 2010. Portofolio dan Investasi: Teori dan Aplikasi. Yogyakarta: Kanisius.

Ulfa, M., Puspitaningtyas, Z., \& Bidhari, SC. 2016. Pengaruh Fluktuasi Nilai Tukar Mata Uang Rupiah-Dolar terhadap Profitabilitas Perusahaan Manufaktur yang Terdaftar di BEI Periode 2010-2014. Jurnal Ekonomi \& Bisnis, 10(2): 131-142.

Vice, LSR, \& Lauw, TT. 2011. Pengaruh Current Ratio, Earning Per Share, dan Price Earnings Ratio terhadap Harga Saham. Jurnal Akuntansi, 3(2): 136-158.

Wicaksono, HA. 2013. Pengaruh Current Ratio, debt to assets Ratio, Total Assets Turnover, return on Equity, Suku Bunga, Kurs Valuta Asing, Inflasi, dan Kas Dividen terhadap Harga Saham. Jurnal Profita: Kajian IImu Akuntansi, 1(4).

Zen, F. 2009. Earning Per Share, Book Value, Economic Value Added dan Harga Saham. Jurnal Manajemen Gajayana, 6(2): 151-162.

Zingales L. 2010. Learning to Live with not-so-efficient markets. Daedelus, 139(4): $31-40$. 